\title{
The limits of transnational justice
}

Citation for published version (APA):

Kurban, D. (2018). The limits of transnational justice: The European Court of Human Rights, Turkey and the Kurdisch conflict. [Doctoral Thesis, Maastricht University]. Maastricht University. https://doi.org/10.26481/dis.20180223dk

Document status and date:

Published: 01/01/2018

DOI:

$10.26481 / \mathrm{dis} .20180223 \mathrm{dk}$

Document Version:

Publisher's PDF, also known as Version of record

\section{Please check the document version of this publication:}

- A submitted manuscript is the version of the article upon submission and before peer-review. There can be important differences between the submitted version and the official published version of record.

People interested in the research are advised to contact the author for the final version of the publication, or visit the DOI to the publisher's website.

- The final author version and the galley proof are versions of the publication after peer review.

- The final published version features the final layout of the paper including the volume, issue and page numbers.

Link to publication

\footnotetext{
General rights rights.

- You may freely distribute the URL identifying the publication in the public portal. please follow below link for the End User Agreement:

www.umlib.nl/taverne-license

Take down policy

If you believe that this document breaches copyright please contact us at:

repository@maastrichtuniversity.nl

providing details and we will investigate your claim.
}

Copyright and moral rights for the publications made accessible in the public portal are retained by the authors and/or other copyright owners and it is a condition of accessing publications that users recognise and abide by the legal requirements associated with these

- Users may download and print one copy of any publication from the public portal for the purpose of private study or research.

- You may not further distribute the material or use it for any profit-making activity or commercial gain

If the publication is distributed under the terms of Article $25 \mathrm{fa}$ of the Dutch Copyright Act, indicated by the "Taverne" license above, 


\section{Summary}

In authoritarian regimes where the state is engaged in violence against a minority group in the context of an ethno-political conflict and is claiming legitimacy from counter-terrorism, what are the potentials and limitations for consequential engagement by a supra-national human rights court? The study seeks to answer this question by focusing on the European Court of Human Rights' (ECtHR) involvement in Turkey's Kurdish conflict as a case study.

Turkey not only ratified the European Convention on Human Rights (ECHR/the Convention) as early as in 1954, but is among its drafters. It has been subject to the oversight of what has been considered to be the most effective human rights regime in the world since its recognition of the compulsory jurisdiction of the ECtHR/Court in 1990. Since 2005, it is an EU accession country a status reserved for countries which uphold the rule of law, guarantee human rights and protect their minorities. Yet, state violence in the Kurdish region continues, showing striking parallels to that in the 1990s, regarding which the ECtHR had issued hundreds of judgments finding multiple human rights violations. Turkey is still governed by an authoritarian politico-legal regime, its security forces engage in gross violations and still enjoy impunity for those they committed in the past, while Kurdish politicians are imprisoned on terrorism charges and stripped of their elected offices solely on account of their democratic activities.

To tackle this puzzle, the study addresses two related research questions on the basis of an interdisciplinary and process-oriented approach. The first is how the ECtHR has approached the gross abuses committed by the Turkish security forces against Kurdish civilians within an emergency setting. I address this question from two perspectives. I draw on the law and society scholarship's bottom-up approach to the use of courts for social change. Drawing on qualitative interviews with key players, as well as archival material, I show how Kurdish lawyers have used the individual petition mechanism to resist state violence since Turkey's recognition of the ECtHR's individual petition mechanism in 1987. By analysing the Court's response over time, I show whether, and if so how, the Convention regime empowers the legal mobilization of minorities in an authoritarian context. In addition, drawing on the judicial impact literature's topdown approach, I turn to legal scholarship and its doctrinal method to inquire whether the Court has exhausted the adjudicatory means available to it in overseeing state violence in Turkey's Kurdish region. Based on a longitudinal analysis of the ECtHR's judgments and decisions concerning state violence in Turkey's Kurdish region since the early 1990s, I aim to understand whether the continuity of gross abuses against Kurdish civilians is only a compliance problem, as depicted in conventional scholarship, or whether it also speaks to more fundamental limitations of the ECtHR.

Second, I also address the more general question of the potential and limitations of supranational courts in addressing the inherent deficiencies of democracy in authoritarian regimes where the majority abuses its numerical superiority to deny minorities their fundamental rights. Given that 
the ECHR is not a minority protection regime and yet has been used by minorities across Europe in their struggle for social justice, I inquire into the jurisdictional, doctrinal and political opportunities and constraints which enable and constrain the ECtHR in ensuring that those who are marginalized on account of their race, ethnicity etc. can exercise their rights under the ECHR. I analyze how the ECtHR has responded to the Kurds' political participation/representation and cultural recognition claims. In light of the Court's individualist approach to rights protection and the limitations of its margin of appreciation and consensus doctrines, I discuss whether, and if so how, the Court has used the jurisprudential tools available to it in overseeing Turkey's embedded cultural assimilation and political disenfranchisement policies against the Kurds.

The study consists of two parts. To explain why Turkey remains an authoritarian regime after over 60-years of engagement with the ECHR, Part I situates Turkey's domestic policies and the European engagement with them in a historical context. Chapter 2 lays out the evolution and progress of Turkey's transition to polyarchy and its tumultuous experience with democracy, constitutionalism, human rights and minority protection against the backdrop of its post-World War II engagement with inter-governmental institutions, including the ECHR regime and the EU. With regard to the former, this chapter is limited to the Convention institutions' engagement until Turkey's recognition of the right of individual petition in 1987. Chapter 3 then provides a historical background on Turkey's Kurdish policies and on the Kurdish political mobilization in response to them, tracing both of them to late $19^{\text {th }}$ century Ottoman era. To address the second research question of this study, the chapter analyses the Court's oversight of Turkey's cultural assimilation and political disenfranchisement policies on the basis of its case law on the Kurds' cultural and political rights. The chapter also looks into the substance and implementation of the EU-induced reforms adopted by successive Turkish governments to address the Kurds' cultural recognition and political participation/representation claims.

Part II is the empirical core of this study; it addresses the first research question on the basis of qualitative fieldwork and archival research. Chapter 4 accounts how a small group of lawyers in Turkey's Kurdish region have used the ECtHR's individual petition mechanism to resist state violence within the emergency context. Drawing on the legal mobilization literature, it traces the varying ways in which Turkey's recognition of the right of individual petition, its efforts to accede to the EU and the post-enlargement reforms of the ECtHR have affected and been affected by Kurdish legal mobilization since the early 1990s. The aim of Chapter 5 is to draw a picture of state violence in the context of the emergency rule in Turkey's Kurdish region by mapping out its actors, acts and victims. It lays out the main perpetrators of state violence; describes the modus operandi of four types of gross violations committed by these actors (enforced disappearances, torture, extrajudicial executions and forced displacement); shows how the perpetrators were insulated by an impunity regime upheld by the Turkish judiciary; and, in an effort to put names and stories to statistics, presents detailed accounts of four cases which resulted in an ECtHR ruling. Chapter 6 focuses on the ECtHR's response to Kurdish legal 
mobilization against state violence by tracing the evolution of the ECtHR's jurisprudence on the four types of gross human rights abuses discussed in Chapter 5. Discussing the evolution of the Court's case law as well as Turkey's execution of these rulings against the backdrop of broader political developments in Europe (the Court's post-enlargement docket crisis and the reforms adopted to address it) and in Turkey (the EU accession process, and the rise and fall of the democratization process), it shows how the ECtHR's engagement in the Kurdish conflict has been affected by these internal and external factors.

The Conclusion chapter revisits the study's research questions in light of its findings, and recent legal and political developments in Turkey. After a brief account of the Turkish Constitutional Court's evolving jurisprudence on the individual complaint mechanism in light of the resumption of state violence in the Kurdish region in 2015 and the collapse of democracy and the rule of law in Turkey since the failed coup attempt in July 2016, the chapter discusses the implications of the study's findings for the judicial impact, legal mobilization and judicial politics scholarships, and puts forth suggestions for further research.

The study concludes that the ECtHR's oversight of state violence in Turkey's Kurdish region has consisted of cycles. The Court has been at its most innovative, boldest and most receptive during the first phase of its engagement until the early 2000s, during which it showed the possibility for a supranational court to have a consequential engagement in state violence. At the same time, even during this Golden Age when Kurdish legal mobilization had its highest impact on the Court's case law, the ECtHR never exhausted the jurisprudential tools and doctrines available to it in its oversight of state violence. As for its oversight of the Kurds' political and cultural rights claims, instead of adopting a contextualized and historically-grounded approach, the ECtHR has treated these cases in isolation and failed to read them against an authoritarian state's decadesold centralization and assimilation policies targeting an ethnic minority.

Based on the in-depth study of the Turkish case, the study argues that in assessing the ECtHR's effectiveness, scholars and practitioners need to engage in differentiated analyses of authoritarian versus democratic regimes. The subsidiarity principle cannot be applied across the board without due attention to differences between the judicial systems and political cultures of contracting parties - a conclusion further supported by recent developments in several post-communist signatory states such as Poland and Hungary. The Turkish case also questions the conventional understandings of representative democracy and the role of regional human rights courts. While the ECtHR's invocation of its margin of appreciation doctrine to defer to governments in their treatment of minority claims may be desirable from the perspective of democracy as far as liberal democratic regimes are concerned, to do so in authoritarian settings serves to provide legitimacy to the disempowerment, repression and disenfranchisement of minority groups. 